Jayapangus Press

Jurnal Penelitian Agama Hindu Terakreditasi Peringkat 2
Volume 5 Nomor 4 (2021)

ISSN : 2579-9843 (Media Online)

http://jayapanguspress.penerbit.org/index.php/JPAH

\title{
KONTRIBUSI KEPEMIMPINAN MODERAT BERLANDASKAN TRI KAYA PARISUDHA, SIKAP SOSIAL, DAN KEMAMPUAN KERJASAMA TERHADAP KINERJA PEGAWAI DI STAHN MPU KUTURAN SINGARAJA
}

\author{
I Gede Suwindia ${ }^{1}$, Ni Nyoman Kurnia Wati \\ ${ }^{12}$ Sekolah Tinggi Agama Hindu Negeri Mpu Kuturan Singaraja \\ ${ }^{1}$ igedesuwindia76@gmail.com, ${ }^{2}$ kurnia_yasa@yahoo.com
}

\begin{abstract}
The progress of an institution, especially a university, is strongly influenced by the performance of its employees. Employee performance is the ability of employees to perform certain skills. Good and bad employee performance can be influenced by many factors, but in this study the contribution of employee performance will be studied based on moderate leadership factors based on Tri Kaya Parisudha, social attitudes, and cooperative abilities. The purpose of this study was to determine how much the contribution of moderate leadership based on Tri Kaya Parisudha, social attitudes, and cooperation skills to the performance of employees at STAHN Mри Kuturan Singaraja, either separately or together. This type of research is ex-post facto research and is included in causal research. The population of this study were all employees in the STAHN Mpu Kuturan Singaraja, totaling 77 people. Because the population in this study was not too large, all populations were immediately used as research samples. The instrument used to measure the research variables was a moderate leadership questionnaire based on Tri Kaya Parisudha, social attitudes, collaboration skills, and employee performance at STAHN Mpu Kuturan Singaraja. The data collected from this study were processed using multiple regression and partial correlation techniques. Based on the results of data analysis, it can be concluded that there is a significant contribution of moderate leadership based on Tri Kaya Parisudha, social attitudes, and cooperation skills on employee performance at STAHN Mpu Kuturan Singaraja.
\end{abstract}

Keywords: Moderate Leadership; Tri Kaya Parisudha; STAHN Employee Performance

\begin{abstract}
Abstrak
Kemajuan sebuah lembaga khususnya perguruan tinggi sangat dipengaruhi oleh kinerja pegawainya. Kinerja pegawai adalah kemampuan pegawai dalam melakukan sesuatu keahlian tertentu. Baik buruknya kinerja pegawai bisa dipengaruhi oleh banyak faktor, namun dalam penelitian ini akan dikaji kontribusi kinerja pegawai berdasarkan faktor kepemimpinan moderat berlandaskan Tri Kaya Parisudha, sikap sosial, dan kemampuan kerjasama. Tujuan dari penelitian ini adalah untuk mengetahui seberapa besar kontribusi kepemimpinan moderat berlandaskan Tri Kaya Parisudha, sikap sosial, dan kemampuan kerjasama terhadap kinerja pegawai di STAHN Mpu Kuturan Singaraja baik secara terpisah maupun bersama-sama. Jenis penelitian ini adalah penelitian ex-post facto dan termasuk dalam Causal research. Populasi penelitian ini adalah seluruh pegawai di lingkungan STAHN Mpu Kuturan Singaraja yang berjumlah 77 orang. Disebabkan jumlah populasi dalam penelitian ini tidak terlalu banyak, maka semua populasi langsung dijadikan sebagai sampel penelitian. Instrumen yang digunakan
\end{abstract}


mengukur variabel penelitian adalah kuesioner kepemimpinan moderat berlandaskan Tri Kaya Parisudha, sikap sosial, kemampuan kerjasama, dan kinerja pegawai STAHN Mpu Kuturan Singaraja. Data yang terkumpul dari penelitian ini diolah dengan teknik regresi ganda dan korelasi parsial. Berdasarkan hasil analisis data, dapat disimpulkan bahwa terdapat kontribusi yang signifikan kepemimpinan moderat berlandaskan Tri Kaya Parisudha, sikap sosial, dan kemampuan kerjasama terhadap kinerja pegawai di STAHN Mpu Kuturan Singaraja.

\section{Kata-Kata Kunci: Kepemimpinan Moderat; Tri Kaya Parisudha; Kinerja Pegawai STAHN}

\section{Pendahuluan}

Budaya organisasi merupakan sistem makna atau nilai yang dianut bersama oleh seluruh anggota organisasi. Robbins and Coulter (1996):289) mengemukakan budaya organisasi adalah sebuah sistem makna bersama yang dianut oleh anggota-anggota yang membedakan organisasi itu dari organisasi-organisasi lainnya. Menurut Kreitner (2005:79) budaya organisasi adalah suatu wujud anggapan yang dimiliki, diterima secara implisit oleh kelompok dan menentukan bagaimana kelompok tersebut rasakan, pikirkan, dan bereaksi terhadap lingkungannya yang beraneka ragam. Sistem makna dan nilai suatu organisasi nantinya menjadi karakteristik khas organisasi tersebut dan akan membuat organisasi berbeda dengan organisasi lain. Budaya organisasi ini biasanya akan tersirat dalam visi misi sebuah organisasi.

STAHN Mpu Kuturan Singaraja adalah salah satu sekolah tinggi agama Hindu yang ada di Bali utara. Visi STAHN Mpu Kuturan Singaraja adalah unggul dan bermartabat berkarakter Tri Kaya Parisudha. Untuk mencapai visi tersebut tentunya dibutuhkan sinergisitas seluruh warga STAHN Mpu Kuturan Singaraja, termasuk juga pegawai STAHN Mpu Kuturan Singaraja. Pegawai yang ada di STAHN Mpu Kuturan harus mampu memahami karakteristik khas dan nilai-nilai budaya organisasi dan berperilaku sesuai dengan yang diharapkan oleh budaya organisasi tersebut. Maka dari itu, untuk menjaga kualitas dan standar kinerja pegawai, perlu diadakan evaluasi secara menyeluruh dan berkesinambungan terhadap kinerja pegawai tersebut.

Menurut Sinambela (2012:5) kinerja pegawai didefinisikan sebagai kemampuan pegawai dalam melakukan sesuatu keahlian tertentu. Kinerja pegawai perlu dievaluasi karena dengan kinerja ini akan diketahui seberapa jauh kemampuan pegawai dalam melaksanakan tugas yang dibebankan kepadanya. Kinerja pegawai diartikan sebagai hasil evaluasi terhadap pekerjaan yang dilakukan individu dibandingkan dengan kriteria yang telah ditetapkan bersama (Robbins and Coulter, 2012:143). Melalui kinerja pegawainya sebuah lembaga/organisasi dapat berjalan dengan baik. Keberhasilan dari sebuah lembaga sangat tergantung dari kinerja pegawainya.

Pegawai yang ada di STAHN Mpu Kuturan tentunya dapat dipastikan mereka berasal dari berbagai daerah. Perbedaan daerah ini menyebabkan adanya perbedaan karakter, perbedaan sifat, maupun perbedaan aliran beragama. Untuk menyelaraskan perbedaan ini tentunya dibutuhkan pemimpin yang mampu mengarahkan perbedaan-perbedaan tersebut menjadi satu kesatuan yang dapat memajukan lembaga.

Salah satu kepemimpinan yang dapat dilakukan untuk menyatukan perbedaanperbedaan di atas adalah kepemimpinan moderat berlandaskan Tri Kaya Parisudha. Kepemimpinan merupakan faktor yang sangat penting dalam menentukan pencapaian tujuan yang telah ditetapkan oleh organisasi. Kepemimpinan merupakan titik sentral dan penentu kebijakan dari kegiatan yang akan dilaksanakan dalam organisasi. Kepemimpinan adalah seni untuk mempengaruhi tingkah laku manusia dan kemampuan membimbing orang (Wiratmadja, 1995:20). Moderat/moderasi disandingkan dengan kata beragama, menjadi moderasi beragama, istilah tersebut berarti merujuk pada sikap mengurangi kekerasan, atau menghindari keekstriman dalam praktik beragama (Saifuddin, 2019). Sedangkan Tri Kaya Parisudha adalah 
tiga perilaku yang baik meliputi berpikir yang baik (manacika), berkata yang baik (wacika) dan berbuat yang baik (kayika). Pikiran yang baik, benar, dan suci akan menimbulkan perkataan dan perbuatan yang baik. Pikiran adalah pengendali ucapan dan perbuatan sehingga perlu adanya pengendalian pikiran supaya perkataan dan perbuatan dapat dikendalikan juga. Demikian pula dengan perkataan, setiap orang lebih lagi seorang pemimpin hendaknya menjaga setiap ucapannya sehingga tidak menimbulkan perselisihan antar bawahan atau orang lain.

Kepemimpinan moderat berlandaskan Tri Kaya Parisudha bertujuan untuk memberikan pemahaman kepada seluruh pegawai untuk bekerja dengan baik, memiliki standar kinerja yang tinggi, dan dalam kegiatan beragama tetap menjungjung keyakinan beragama Hindu seutuhnya. Para pegawai maupun seluruh warga kampus diharapkan tidak mengikuti aliran-aliran yang kurang sesuai dengan ajaran agama Hindu yang ada di Bali pada khususnya dan Indonesia pada umumnya. Hal ini bertujuan agar seluruh pegawai memiliki pandangan dan keyakinan yang sama dalam bekerja, sehingga mereka merasa satu keluarga, satu keyakinan, dan memiliki satu tujuan untuk memajukan lembaga STAHN Mpu Kuturan Singaraja.

Selain faktor kepemimpinan moderat berlandaskan Tri Kaya Parisudha, faktor lain yang diprediksi mempengaruhi kinerja pegawai adalah sikap sosial. Herawati (dalam Dimyati dan Mudjiono, 2014) menjelaskan bahwa sikap sosial adalah kesadaran individu yang menentukan perbuatan yang nyata, yang berulang-ulang terhadap obyek sosial. Rusmaja (2013:59) menjelaskan di dalam perkembangannya, sikap banyak dipengaruhi oleh lingkungan, norma-norma atau kelompok. Hal ini akan mengakibatkan perbedaan antara sikap dan individu yang satu dengan yang lainnya karena perbedaan pengaruh atau lingkungan yang diterima. Sikap tidak akan terbentuk tanpa interaksi manusia terhadap objek tertentu atau suatu objek. Sikap sosial terbentuk karena adanya interaksi sosial yang dialami oleh individu. Interaksi sosial mengandung arti lebih dari sekedar kontak sosial dan hubungan antar individu sebagai anggota kelompok sosial. Dalam interaksi sosial terjadi hubungan saling mempengaruhi diantara individu yang satu dengan individu yang lain, terjadi hubungan timbal balik yang turut mempengaruhi pola perilaku masing-masing individu sebagai anggota masyarakat. Lebih dari itu, interaksi sosial meliputi hubungan antara individu dengan lingkungan fisik maupun lingkungan psikologis di sekelilingnya.

Pegawai yang memiliki sikap sosial yang baik, tentunya tidak akan canggung untuk bertanya maupun meminta saran kepada rekan kerja yang lain untuk mencari solusi dari permasalahan yang dihadapinya dalam bekerja. Selain itu, pegawai yang memiliki sikap sosial yang baik, pastinya dalam bekerja tidak akan mementingkan pekerjaan sendiri saja. Tetapi juga selalu siap membantu kapan pun dan dimana pun saat dibutuhkan oleh teman-teman di tempat kerjanya. Hal ini tentunya berdampak positif terhadap peningkatan kinerja pegawai.

Hal ini sejalan dengan hasil penelitian Samsuri dan Hari (2017) tentang pengaruh sikap dan motivasi terhadap kinerja karyawan pada MTSN Takeran Kabupaten Magetan. Hasil penelitian menunjukkan bahwa sikap mempunyai pengaruh yang positif terhadap Kinerja Karyawan MTsN Takeran Kabuparen Magetan. Artinya apabila Sikap kerja semua karyawan baik atau mampu mengendalikan perilaku, emosional serta sikap karyawan yang mampu mengendalikan diri masing masing maka, kinerja karyawan akan meningkat.

Faktor lain yang juga diprediksi memberikan kontribusi yang besar dalam kinerja pegawai adalah kemampuan kerjasama. Bachtiar (2004) menyatakan bahwa kerjasama merupakan sinergisitas kekuatan dari beberapa orang dalam mencapai satu tujuan yang diinginkan. Kerjasama akan menyatukan kekuatan ide-ide yang akan mengantarkan pada kesuksesan. Sedangkan Davis (dalam Dewi, 2006) mengemukakan bahwa bahwa kerjasama adalah keterlibatan mental dan emosional orang-orang di dalam situasi kelompok yang mendorong mereka untuk memberikan kontribusi kepada tujuan kelompok atau berbagai tanggung jawab pencapaian tujuan. 
Pendapat di atas, memperlihatkan bahwa kerjasama merupakan hal yang sangat penting dalam sebuah kelompok atau lembaga. Kemampuan kerjasama yang tinggi dimiliki oleh seluruh pegawai, tentunya membuat mereka mampu untuk bersatu dalam menunjukkan kinerja yang terbaik sehingga tercapai tujuan lembaga STAHN Mpu Kuturan Singaraja secara optimal.

Penelitian yang mengkaji tentang kerjasama dilakukan oleh Ibrahim (2021) dengan judul pengaruh kerjasama tim terhadap kinerja karyawan di PT Lion Superindo. Hasil penelitian menunjukkan terdapat pengaruh positif dan signifikan kerjasama tim terhadap kinerja karyawan PT. Lion Superindo hal tersebut dapat dibuktikan dari nilai t-hitung 7,77 > ttabel 2,01. Hal tersebut menandakan bahwa semakin baik penerapan kerjasama tim yang dilakukan perusahaan maka akan semakin meningkat pula kinerja karyawan pada PT. Lion Superindo.

Berdasarkan latar belakang di atas, terlihat bahwa kepemimpinan moderat berlandaskan Tri Kaya Parisudha, sikap sosial, dan kemampuan kerjasama memberikan kontribusi kinerja pegawai. Namun seberapa besar kontribusi tersebut belum diketahui secara pasti. Maka dari itu, pada penelitian ini akan mengambil judul tentang "Kontribusi Kepemimpinan Moderat Berlandaskan Tri Kaya Parisudha, Sikap Sosial, dan Kemampuan Kerjasama Terhadap Kinerja Pegawai di STAHN Mpu Kuturan Singaraja.

\section{Metode}

Penelitian ini adalah penelitian "ex-post facto". Penelitian "ex-post facto" adalah penelitian yang bertujuan menemukan penyebab yang memungkinkan perubahan perilaku, gejala atau fenomena yang disebabkan oleh suatu peristiwa, perilaku, gejala atau fenomena yang disebabkan oleh suatu peristiwa, perilaku atau hal-hal yang menyebabkan perubahan pada variabel bebas secara keseluruhan sudah terjadi (Widarto, 2013).

Populasi pada penelitian ini adalah seluruh pegawai di lingkungan STAHN Mpu Kuturan Singaraja yang berjumlah 77 orang. Dikarenakan jumlah populasi dalam penelitian ini tidak terlalu banyak, maka seluruh pegawai di lingkungan STAHN Mpu Kuturan Singaraja langsung dijadikan sebagai sampel penelitian.

Variabel yang digunakan pada penelitian ini ada dua, yakni variabel bebas dan variabel terikat. Variabel bebas (X) dalam penelitian ini terdiri dari kepemimpinan moderat berlandaskan Tri Kaya Parisudha (X1), sikap sosial (X2), dan kemampuan kerjasama (X3). Sedangkan variabel terikat (Y) dalam penelitian ini yaitu kinerja pegawai STAHN Mpu Kuturan Singaraja. Adapun konstelasi variabel yang digunakan pada penelitian ini adalah sebagai berikut.

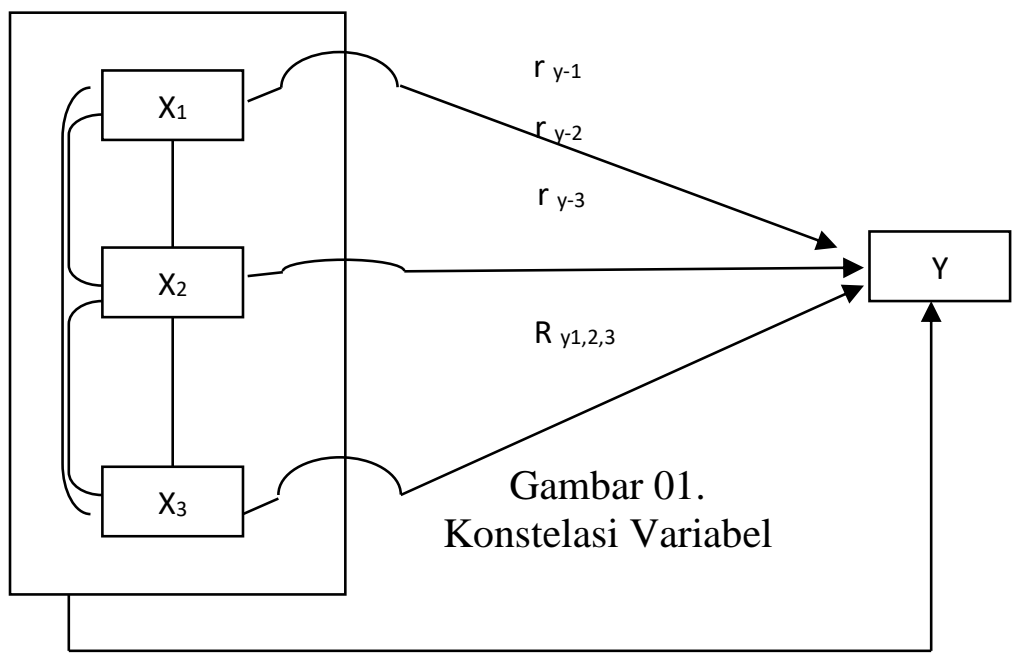


Keterangan :

$\mathrm{X}_{1}$ : Kepemimpinan moderat berlandaskan Tri Kaya Parisudha

$\mathrm{X}_{2}$ : Sikap sosial

$\mathrm{X}_{3}$ : Kemampuan kerjasama

Y : Kinerja pegawai

Metode pengumpulan data yang digunakan pada penelitian ini adalah metode kuesioner, sehingga instrumen yang digunakan pada penelitian ini adalah: 1) kepemimpinan moderat berlandaskan Tri Kaya Parisudha, 2) sikap sosial, 3) kemampuan kerjasama, dan 4) kuesioner kinerja pegawai STAHN Mpu Kuturan Singaraja. Analisis data pada penelitian ini dibagi menjadi tiga tahapan yakni: 1) tahap deskripsi data, 2) tahap pengujian persyarat analisis, 3) tahap pengujian hipotesis. Pendeskripsian data dilakukan dengan mencari harga rerata (M), standar deviasi (SD), modus (Mo), dan median (Me) setiap variabel yang diteliti. Tahap pengujian persyarat analisis dilakukan beberapa uji prasyarat diantaranya: 1) Uji Normalitas Sebaran Data, 2) Uji Linieritas dan Keberartian Koefisien Regresi, 3)Uji Multikolinieritas, 4) Uji Heterokedastisitas, dan 5)Uji Autokorelasi. Tahap pengujian hipotesis menggunakan teknik regresi ganda dan korelasi parsial dengan rumus sebagai berikut.

\section{Regresi Ganda}

$\operatorname{Ry}(123)=\sqrt{\frac{a_{1} \sum x_{1} y+a_{2} \sum x_{2} y+a_{3} \sum x_{3} y}{\sum y^{2}}}$

Untuk uji signifikan nilai R menggunakan rumus F sebagai berikut.

$F_{\text {reg }}=R^{2}(n-m-1)$ $\underline{\mathrm{m}\left(1-\mathrm{R}^{2}\right.}$ (Sugiyono, 2017)

2. Signifikansi Garis regresi

$\hat{\mathrm{Y}}=\mathrm{a}+\mathrm{b}_{1} \mathrm{X}_{1}+\mathrm{b}_{1} \mathrm{X}_{2}+\mathrm{b}_{3} \mathrm{X}_{3} \quad$ (Sugiyono, 2017)

Untuk menguji signifikan garis regresi di atas digunakan rumus sebagai berikut.

$\mathrm{F}_{\text {res }}=\frac{\mathrm{RJK}_{\mathrm{reg}}}{\mathrm{RJK}_{\mathrm{res}}} \quad$, dengan derajat kebebasan $(\mathrm{dk})=(\mathrm{m}):(\mathrm{n}-\mathrm{m}-1)$

Keterangan:

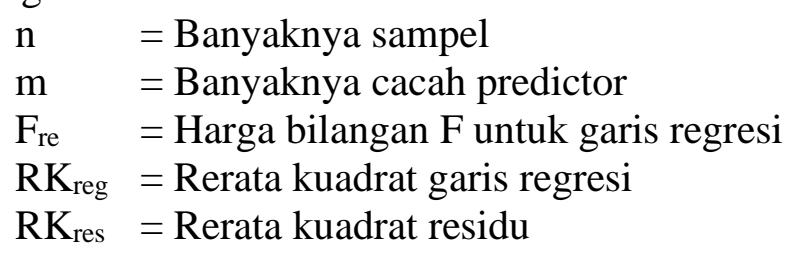

Kaidah keputusannya adalah dengan menggunakan $\alpha=0,05$ dan $\mathrm{dk}(\mathrm{m}):(\mathrm{n}-\mathrm{m}-1)$. Jika $F_{\text {hitung }}>F_{\text {tabel }}(P<0,05)$ maka garis regresi signifikan, sebaliknya jika $F_{\text {hitung }}<F_{\text {tabel }}$ maka garis regresi tidak signifikan.

3. Korelasi Parsial

Untuk mengetahui korelasi parsial yaitu korelasi antara satu variabel bebas dengan variabel terikat dengan mengendalikan variabel lainnya digunakan rumus korelasi parsial jenjang kedua dengan rumus sebagai berikut. 


$$
\begin{aligned}
r_{1 y-2,3} & =\frac{r_{1 y-2}-\left(r_{1,3-2}\right)\left(r_{3 y-2}\right)}{\sqrt{\left(1-r_{1,3-2}^{2}\right)\left(1-r^{2}{ }_{3 y-3}\right)}} \\
r_{2 y-1,3} & =\frac{r_{2 y-2}-\left(r_{2,3-1}\right)\left(r_{3 y-1}\right)}{\sqrt{\left(1-r_{2,3-1}^{2}\right)\left(1-r_{3 y-1}^{2}\right)}} \\
r_{3 y-1,2} & =\frac{r_{3 y-2}-\left(r_{2,3-1}\right)\left(r_{2 y-2}\right)}{\sqrt{\left(1-r^{2}{ }_{2,3-2}\right)\left(1-r^{2}{ }_{2 y-1}\right)}}
\end{aligned}
$$

(Hadi, 2014:50)

Untuk menguji signifikansi nilai korelasi parsial digunakan uji t-student, dengan kaidah keputusan menggunakan $\alpha=0,05 \mathrm{dk}=\mathrm{n}-\mathrm{m}-1$, jika thitung $>\mathrm{t}_{\text {tabel }}$ maka Ho ditolak, berarti signifikan, sebaliknya jika $t_{\text {hitung }}<t_{\text {tabel }}$ maka Ho diterima, berarti tidak signifikan. Untuk menganalisis digunakan program SPSS-17.00 for windows.

\section{Hasil Dan Pembahasan}

\section{Terdapat Kontribusi yang Signifikan Kepemimpinan Moderat Berlandaskan Tri Kaya Parisudha Terhadap Kinerja Pegawai}

Berdasarkan hasil analisis, hipotesis pertama menyatakan bahwa terdapat kontribusi yang signifikan kepemimpinan moderat berlandaskan Tri Kaya Parisudha terhadap kinerja pegawai di STAHN Mpu Kuturan dengan F hitung sebesar 65,281 dan kontribusi sebesar $46,5 \%$.

Hasil penelitian di STAHN Mpu Kuturan, kepemimpinan moderat berlandaskan Tri Kaya Parisudha memiliki kontribusi yang signifikan terhadap kinerja pegawai. Hal ini bisa diamati melalui kuesioner yang disebarkan pada pegawai di STAHN Mpu Kuturan menyatakan bahwa pemimpin cepat mengambil dalam keputusan, menekankan pada hasil dan tujuan, membantu penerapan keputusan, serta memperkuat relasi dengan pemerintah dan masyarakat setempat. Relasi yang dibangun oleh pimpinan berupa kerjasama dengan pemerintah kabupaten Buleleng, Universitas Panji Sakti Singaraja, Universitas Pendidikan Ganesha, kantor pos, RRI Singaraja, dinas pariwisata, KPPN Buleleng dan lainnya baik tingkat daerah maupun pusat. Hal ini dilakukan dalam upaya memudahkan kinerja pimpinan dan juga membangun hubungan yang baik dengan lembaga-lembaga yang tersebut.

Selain itu pimpinan STAHN Mpu Kuturan juga menyediakan sumber-sumber fasilitas yang diperlukan misalnya untuk memudahkan dalam memahami lontar maka pimpinan mengadakan Kerjasama dengan pemerintah kabupaten Buleleng Khususnya Gedong Krtya untuk memberikan ijin kampus mengakaji atau meneliti lebih lanjut tentang lontar. Dalam hal memperkuat kebijakan organisasi, pimpinan selalu mengambil keputusan berdasarkan persetujuan dari Senat STAHN Mpu Kuturan dan membuatkan surat keputusan dari setiap kebijakan yang diambil sehingga ada dasar hukum dalam setiap kegiatan yang dibuat. Pimpinan juga selalu memberikan dorongan dan penghargaan pada pegawai yang kinerjanya bagus, ramah dan selalu melakukan pendekatan, serta mendorong semangat kerja.

Kepemimpinan di STAHN Mpu Kuturan juga memandang berbagai persoalan dengan pikiran terbuka, mencari masukan dan nasehat dengan pikiran terbuka serta kebijakan, serta selalu melibatkan orang lain dengan tepat dalam pengambilan keputusan. Hal ini dibuktikan dengan setiap hari Senin diadakan Coffe Morning yang bertujuan membahas permasalahanpermasalahan kampus, mencari solusi serta masukan dari para pejabat sehingga masalah yang dihadapi dapat diselesaikan dengan terbuka dan tepat sasaran.

Berdasarkan pemaparan di atas sifat kepemimpinan yang moderat berlandaskan Tri Kaya Parisudha sangat baik dilakukan dalam melaksanakan kepemimpinan di sebuah organisasi. Sikap pemimpin yang menghindarkan perilaku ekstrem, tidak berpihak pada suatu 
golongan saja toleransi antar sesama manusia, memiliki pemikiran yang rasional, sikap yang terbuka, dan rendah hati tentunya akan membangun situasi kinerja yang harmonis.

Pemimpin yang memiliki pikiran baik, benar, dan suci akan menimbulkan perkataan dan perbuatan yang baik. Pikiran adalah pengendali ucapan dan perbuatan sehingga perlu adanya pengendalian pikiran supaya perkataan dan perbuatan dapat dikendalikan juga. Demikian pula dengan perkataan, setiap orang lebih lagi seorang pemimpin hendaknya menjaga setiap ucapannya sehingga tidak menimbulkan perselisihan antar bawahan atau orang lain. Sejalan dengan penelitian ini, Jamaludin, (2017) meneliti pengaruh gaya kepemimpinan terhadap kinerja karyawan pada PT.Kaho Indahcitra Garment Jakarta. Simpulan penelitian menyatakan bahwa ada pengaruh yang positif dan signifikan antara gaya kepemimpinan terhadap kinerja karyawan di PT. Kaho Indahcitra Garment Jakarta. Barkhowa, dkk (2017) meneliti tentang pengaruh kepemimpinan terhadap kinerja karyawan dengan kedisiplinan karyawan sebagai variabel intervening. Hasil penelitian membuktikan bahwa kepemimpian memiliki pengaruh positif terhadap kinerja karyawan.

\section{Terdapat Kontribusi Sikap Sosial Terhadap Kinerja Pegawai}

Berdasarkan hasil analisis, hipotesis kedua menyatakan bahwa terdapat kontribusi yang signifikan sikap sosial terhadap kinerja pegawai di STAHN Mpu Kuturan Singaraja dengan F hitung sebesar 56,297 dan kontribusi sebesar 42,9\%.

Hasil penelitian di STAHN Mpu Kuturan tentang sikap sosial pegawai dapat dilihat dari hasil kuesioner bahwa pegawai di STAHN Mpu Kuturan memiliki sikap sosial yang baik diantaranya keterbukaan. Diamati dalam kesehariannya pegawai di STAHN Mpu kuturan akan berterus terang pada teman jika sedang mengalami suatu kendala dalam pekerjaanya, memiliki sikap yang jujur, mampu menerima dan menghargai perbedaan suku, agama, ras, etnis antar sesama, serta memiliki rasa tenggang rasa dan toleransi terhadap orang lain. Hal ini dibuktikan dengan adanya perkumpulan yang bernama Suka Duka Eka Cita Dharma Bhawana yang didirikan atas kesadaran untuk saling berbagi suka dan duka bersama seluruh pegawai di lingkungan kampus STAHN Mpu Kuturan. Kegiatan dalam organisasi Suka Duka Eka Cita Dharma Bhawana ini meliputi kunjungan pada anggota yang sedang mengalami suka maupun duka dan juga sebagai pengempon Pura Kerta Gama yang ada di lingkungan STAHN Mpu Kuturan. Suka yang dimaksud dalam kegiatan ini adalah jika ada anggota yang menikah, tigabulanan, dan potong gigi. Sedangkan duka yang dimaksud apabila ada kematian dari orang tua atau suami/istri, serta yang bersangkutan sakit/opname.

Demikian halnya dilihat dari empati para pegawai menunjukkan sikap yang hangat kepada teman, merasakan apa yang dirasakan orang lain, dan peduli terhadap sesama maupun lingkungan sekitarnya. Hal ini bisa dibuktikan dengan dukungan yang besar dari para pegawai jika ada himbauan untuk melakukan bakti sosial ataupun sumbangan sukareka jika ada saudara yang tertimpa musibah. Juga sebelum masa pandemic Covid-19 setiap hari Jumat akan diadakan Jumat bersih. Kegiatannya adalah membersihkan lingkungan kampus dan sekitarnya untuk menjaga kebersihan dan keasrian lingkungan. Ini merupakan bentuk kepedulian terhadap lingkungan sekitar. Dalam berkomunikasi, para pegawai di STAHN Mpu Kuturan santun dalam bertutur kata dan juga memiliki rasa percaya diri berkomunikasi dalam forum. Hal ini dibuktikan dengan terlibatnya pegawai pada kegiatan-kegiatan kampus dan luar kampus yang menuntut adanya komunikasi dalam forum. Pegawai tidak sungkan dalam menyampaikan pendapatnya dalam forum, bahkan ada beberapa pegawai yang menjadi narasumber dalam kegiatan-kegiatan kampus maupun luar kampus.

Indikator lain yang digunakan dalam mengukur sikap sosial pegawai adalah kesetiaan. Kesetiaan yang dimaksud adalah pegawai tidak membawa permasalahan di kantor keluar dari Lembaga, menjaga kerahasiaan pekerjaan yang sedang dikerjakan, tidak ingin mencampuri pekerjaan orang lain, serta menghormati privasi teman dalam bekerja. Selama ini sikap setia ini sudah ditunjukkan oleh pegawai di STAHN Mpu Kuturan. 
Berdasarkan pemaparan di atas, sikap sosial sangat mendukung kinerja pegawai. Pegawai yang memiliki sikap sosial yang baik tentunya juga bekerja dengan baik. Sikap sosial yang baik adalah memiliki keterbukaan, empati, mampu berkomunikasi dengan baik, dan memiliki kesetiaan terhadap tempat kerjanya.

Penelitian yang sejalan dengan penelitian ini dilakukan oleh Pranjia (2020) mengkaji sikap sosial melalui judul implementasi sikap spiritual dan sikap sosial dalam sistem full day school. Hasil penelitian menunjukkan bahwa implementasi sikap spiritual dan sikap sosial dalam sekolah bersistem full day school dilakukan dengan cara (1) Perencanaan program pengembangan karakter siswa, (2) Pelaksanaan program pengembangan karakter siswa, (3) Penilaian program pengembangan karakter siswa terdiri atas penilaian dalam maupun di luar Kegiatan belajar Mengajar.

Sya'baniah, (2019) mengkaji pengaruh sikap dan kepribadian terhadap kinerja pegawai. Hasil penelitian menunjukkan bahwa bahwa kepuasan kerja, komitmen organisasi, dan keterlibatan kerja berpengaruh signifikan dan positif terhadap kinerja karyawan, dan hipotesis yang menyatakan bahwa kepuasan kerja, komitmen organisasi, dan keterlibatan kerja berpengaruh signifikan dan positif terhadap kinerja karyawan pada PT. Duta Marga Silima di Jakarta dinyatakan benar dan dapat diterima.

\section{Terdapat Kontribusi yang Signifikan Kerjasama Terhadap Kinerja Pegawai}

Berdasarkan hasil analisis, hipotesis ketiga menyatakan bahwa terdapat kontribusi yang signifikan kerjasama terhadap kinerja pegawai di STAHN Mpu Kuturan Singaraja dengan F hitung 37,315 dan kontribusi sebesar 33,2\%.

Hasil yang diperoleh berdasarkan kuesoiner adalah pegawai memiliki kesadaran mengerjakan sesuatu tanpa harus disuruh terlebih dahulu, berani meminta maaf sekaligus menanggung beban atas kesalahan yang saya lakukan dan tidak mengulangi kesalahan yang sama, berusaha menyelesaikan pekerjaan yang dibebankan tepat waktu, memiliki jiwa "melayani" dengan sepenuh hati sekaligus menghilangkan pemikiran "Siapa yang butuh, dia yang harus menghubungi saya", serta melakukan pekerjaan sesuai tugas dan fungsi sebagai pegawai. Pegawai juga menyatakan bahwa tidak akan meninggalkan tugas utama jika belum selesai, memberikan masukan terhadap rekan kerja yang sedang mengalami kendala, membantu rekan kerja saat dibutuhkan tanpa melalaikan tugas utama, berdiskusi dengan atasan jika ada tugas yang belum dipahami, serta ikut pelatihan kepegawaian untuk meningkatkan kemampuannya.

Pegawai akan belajar lagi jika ada tugas yang dipahami, bahkan bersedia pulang terlambat untuk menyelesaikan tugas. Mereka tidak ragu mengeluarkan dana sendiri jika tugas yang dilakukan membutuhkan dana mendesak dan belum bisa diamprahkan, perbaiki tugastugas yang dianggap belum maksimal oleh atasan, berdiskusi terlebih dahulu dengan atasan dalam suatu pekerjaan, mendukung tujuan lembaga melalui kinerja, serta bekerja mengacu pada tujuan yang ditetapkan. Para pegawai juga tergabung dalam grup pegawai untuk mempercepat penyampaian informasi, mengkomunikasikan secara intensif tugas yang sedang dikerjakan, sebelum mengambil tugas yang lain, maka akan fokus menyelesaikan satu tugas terlebih dahulu, mendahulukan tugas yang mendesak, serta mememeriksa dengan teliti tugas yang dikerjakan sebelum diserahkan pada atasan.

Berdasarkan kemampuan kerjasama di atas, maka kampus STAHN Mpu Kuturan dapat berkembang dengan baik. Sistem birokrasinya juga berjalan sesuai aturan dan jarang ada kegagalan dalam melakukan sebuah kegiatan. Berkat kemampuan kerjasama antar pegawai maka tercipta kinerja yang baik di STAHN Mpu Kuturan.

Wulandari (2015) mengkaji penelitian dengan judul Peningkatan Kemampuan Kerjasama dalam Tim Melalui Pembelajaran Berbasis Lesson Study. Hasil penelitian menunjukkan bahwa terjadi peningkatan kualitas proses pembelajaran. Sejalan dengan itu, Hidayat (2019) mengkaji pengaruh gaya kepemimpinan, kerjasama tim dan kompensasi 
terhadap kinerja karyawan melalui kepuasan kerja pada PT. dunia Barusa Banda Aceh. Hasil penelitian menunjukkan bahwa gaya kepemimpinan, kerjasama tim, kompensasi, kinerja karyawan, dan kepuasan kerja sudah berjalan dengan baik. Hasil gaya kepemimpinan, kerjasama tim dan kompensasi berpengaruh terhadap kinerja karyawan, gaya kepemimpinan secara tidak langsung berpengaruh terhadap kinerja karyawan melalui kepuasan kerja, kerjasama tim secara tidak langsung berpengaruh terhadap kinerja karyawan melalui kepuasan kerja karyawan dan kompensasi secara tidak langsung berpengaruh terhadap kinerja karyawan melalui kepuasan kerja karyawan.

\section{Terdapat Kontribusi Kepemimpinan Moderat Berlandaskan Tri Kaya Parisudha, Sikap Sosial, dan Kerjasama Terhadap Kinerja Pegawai}

Berdasarkan hasil analisis, hipotesis penelitian menyatakan bahwa secara bersamasama, terdapat kontribusi yang signifikan kepemimpinan moderat berlandaskan Tri Kaya Parisudha, sikap sosial, dan kemampuan kerjasama terhadap kinerja pegawai di STAHN Mpu Kuturan Singaraja dengan F hitung sebesar 38,172 dan kontribusi sebesar 61,1\%.

Kepemimpinan moderat berlandaskan Tri Kaya Parisudha bertujuan untuk memberikan pemahaman kepada seluruh pegawai untuk bekerja dengan baik, memiliki standar kinerja yang tinggi, dan dalam kegiatan beragama tetap menjunjung keyakinan beragama Hindu seutuhnya. Seluruh pegawai harus memiliki pandangan dan keyakinan yang sama dalam bekerja, sehingga mereka merasa satu keluarga, satu keyakinan, dan memiliki satu tujuan untuk memajukan lembaga STAHN Mpu Kuturan Singaraja.

Selain faktor kepemimpinan moderat berlandaskan Tri Kaya Parisudha, faktor lain yang terbukti mempengaruhi kinerja pegawai adalah sikap sosial. Ahmadi (1999) "menyebutkan bahwa sikap sosial adalah kesadaran individu yang menentukan perbuatan nyata dan berulang-ulang terhadap obyek sosial". Sikap sosial ini tidak dinyatakan oleh seorang tetapi diperhatikan oleh orang-orang sekelompoknya. Selanjutnya Ahmadi juga menjelaskan bahwa sikap terdiri dari: 1) sikap positif yaitu sikap yang menunjukan atau memperlihatkan, menerima, mengakui, menyetujui, serta melaksanakan norma-norma yang berlaku dimana individu itu berada, 2) sikap negatif yaitu sikap yang menunjukan atau memperlihatkan, penolakan atau tidak menyetujui terhadap norma-norma yang berlaku dimana individu itu berada. Sikap positif/negatif ini tentu saja berhubungan dengan norma.

Pegawai yang memiliki sikap sosial yang baik, tentunya tidak akan canggung untuk bertanya maupun meminta saran kepada rekan kerja yang lain untuk mencari solusi dari permasalahan yang dihadapinya dalam bekerja. Selain itu, pegawai yang memiliki sikap sosial yang baik, pastinya dalam bekerja tidak akan mementingkan pekerjaan sendiri saja. Tetapi juga selalu siap membantu kapan pun dan dimana pun saat dibutuhkan oleh teman-teman di tempat kerjanya. Hal ini tentunya berdampak positif terhadap peningkatan kinerja pegawai.

Faktor lain yang juga diprediksi memberikan kontribusi yang besar dalam kinerja pegawai adalah kemampuan kerjasama. Menurut Johnson \& Johnson (1991) Kerjasama adalah bekerja bersama untuk mencapai tujuan yang diinginkan bersama. Kerjasama merupakan hal yang sangat penting dalam sebuah kelompok atau lembaga. Kemampuan kerjasama yang tinggi dimiliki oleh seluruh pegawai, tentunya membuat mereka mampu untuk bersatu dalam menunjukkan kinerja yang terbaik sehingga tercapai tujuan lembaga STAHN Mpu Kuturan Singaraja secara optimal.

Sejalan dengan hasil penelitian ini, Arifin, (2020) mengkaji penelitian yang berjudul pengaruh kepemimpinan dan kerjasama tim terhadap kepuasan kerja dan kinerja karyawan pada sentra keripik sukun di Kabupaten Sumenep. Hasil penelitian menunjukkan bahwa kepemimpinan memberi pengaruh yang tidak langsung terhadap kinerja karyawan melalui kepuasan kerja. Kerjasama tim berpengaruh langsung dan signifikan terhadap kinerja karyawan, juga memberi pengaruh yang tidak langsung yang positif dan signifikan terhadap kinerja karyawan melalui kepuasan kerja. 
Jadi dapat disimpulkan bahwa kepemimpinan moderat berlandaskan Tri Kaya Parisudha, sikap sosial, dan kemampuan kerjasama mampu memberikan kontribusi terhadap kinerja pegawai.

\section{Kesimpulan}

Berdasarkan hasil analisis data penelitian dapat disimpulkan bahwa: 1) Terdapat kontribusi yang signifikan kepemimpinan moderat berlandaskan Tri Kaya Parisudha terhadap kinerja pegawai di STAHN Mpu Kuturan Singaraja dengan kontribusi sebesar 46,5\% dan sumbangan efektif sebesar $28,81 \%, 2)$ Terdapat kontribusi yang signifikan sikap sosial terhadap kinerja pegawai di STAHN Mpu Kuturan Singaraja dengan kontribusi sebesar 42,9\% dan sumbangan efektif sebesar 16,55\%,3) Terdapat kontribusi yang signifikan kemampuan kerjasama terhadap kinerja pegawai di STAHN Mpu Kuturan Singaraja dengan kontribusi sebesar 33,2\% dan sumbangan efektif sebesar 15,70\%, 4) Secara bersama-sama, terdapat kontribusi yang signifikan kepemimpinan moderat berlandaskan Tri Kaya Parisudha, sikap sosial, dan kemampuan kerjasama terhadap kinerja pegawai di STAHN Mpu Kuturan Singaraja dengan kontribusi sebesar $61,1 \%$.

Saran yang dapat diberikan dalam penelitian ini diantaranya: 1) pegawai disarankan untuk selalu bekerja dengan sepenuh hati, sehingga pelayanan prima dapat diwujudkan bagi pengguna layanan. Selain itu dalam penelitian ini terbukti bahwa sikap sosial dan kemampuan kerjasama memberikan kontribusi yang signifikan terhadap kinerja pegawai, maka dari itu seluruh pegawai diharapkan untuk selalu meningkatkan sikap sosial dan kemampuan Kerjasama, 2) pimpinan disarankan untuk selalu memberikan contoh serta mampu mangayomi bawahannya dengan mengimplementasikan kepemimpinan moderat berlandaskan Tri Kaya Parisudha sebagai pedoman dalam menjalankan tugasnya, dan 3) peneliti lain disarankan untuk mengembangkan penelitian ini dengan menjadikannya sebagai rujukan atau referensi dalam mengembangkan penelitian-penelitian selanjutnya.

\section{Daftar Pustaka}

Ahmadi, A. (1999). Psikologi Sosial. Jakarta: Rineka Cipta.

Arifin, A. (2020). Pengaruh Kepemimpinan dan Kerjasama Tim Terhadap Kepuasan Kerja dan Kinerja Karyawan. Journal.Feb.Unmul.Ac.Id, 17(2).

Bachtiar, D. (2004). Pengaruh Motivasi Dan Lingkungan Kerja Terhadap Kinerja Karyawan. Management Analysis Journal, 1(1).

Barkhowa, Mokhammad Khukaim, Fitri Lukiastuti, dan H. A. S. (2017). Pengaruh Kepemimpinan Terhadap Kinerja Karyawan Dengan Kedisiplinan Karyawan Sebagai Variabel Intervening. Jurnal Magisma, 5(1).

Dewi. (2006). Indikator-indikator Kerjasama. Psychologymania.

Dimyati, M. (2014). Belajar dan Pembelajaran. Jakarta. Rineka Cipta.

Hadi, S. (2014). Metodologi Research. Yogyakarta: Andi Offset.

Hidayat, Syarif, D. (2019). Pengaruh Gaya Kepemimpinan, Kerjasama Tim Dan Kompensasi Terhadap Kinerja Karyawan Melalui Kepuasan Kerja pada PT. dunia Barusa Banda Aceh. Jurnal Perspektif Ekonomi Darussalam, 5(1).

Ibrahim, Farhan Elang, D. (2021). Pengaruh Kerjasama Tim Terhadap Kinerja Karyawan di PT Lion Superindo. Jurnal ARASTIRMA Fakultas Ekonomi Program Studi Manajemen UNPAM, 1(2), 316-325.

Jamaludin, A. (2017). Pengaruh Gaya Kepemimpinan Terhadap Kinerja Karyawan pada PT.Kaho Indahcitra Garment. Journal of Applied Business and Economics, 3(3), 161169.

Johnson DW \& Johnson, R, T. (1991). Learning Together and Alone. Allyn and Bacon: Massa Chussetts.

Kreitner, R. \& A. K. (2005). Perilaku Organisasi. Jakarta: Salemba Empat. 
Pranjia, U. R. dan I. M. U. (2020). Implementasi Sikap Spiritual dan sikap Sosial Dalam Sistem full Day School. Jurnal Pendidikan Islam, 11(1).

Robbins, Stephen P. and Coulter, M. (1996). Perilaku Organisasi Edisi ke 7 (Jilid II). Jakarta: Prehallindo.

Robbins, Stephen P. and Coulter, M. (2012). Management. USA: Pearson Education Limited.

Rusmaja, M. (2013). Pengaruh Impelementasi Model pembelajaran role playing Terhadap Sikap Sosial Dan Hasil Belajar IPS Di Kelas IV Gugur 1 Busungbiu. UNDIKSHA.

Saifuddin, L. H. (2019). Moderasi Beragama. Jakarta: Badan Litbang dan Diklat Kementerian Agama RI.

Samsuri dan Hari Purwanto. (2017). Pengaruh Sikap dan Motivasi Terhadap Kinerja Karyawan pada MTsN Takeran Kabupaten Magetan. Jurnal Capital, 1(1).

Sinambela, L. (2012). Kinerja Pegawai: Teori, Pengukuran dan Implikasi. Yogyakarta: Graha Ilmu.

Sugiyono. (2017). Statistika untuk Penelitian. Bandung: Alfabeta.

Sya'baniah, S. I. dkk. (2019). Pengaruh Sikap Dan Kepribadian Terhadap Kinerja Pegawai (Studi pada Dinas Sosial Kabupaten Ciamis). Business Management And Entrepreneurship Journal, 4(1).

Widarto. (2013). Penelitian Ex Post Facto. Makalah Seminar. Disampaikan pada kegiatan pelatihan metodologi penelitian pendidikan di Fakultas Teknik Universitas Negeri Yogyakarta tanggal 27 s.d. 28 Juni 2013.

Wiratmadja, G. (1995). Kepemimpinan Hindu. Denpasar: Yayasan Dharma Narada.

Wulandari. (2015). Peningkatan Kemampuan Kerjasama dalam Tim Melalui Pembelajaran Berbasis Lesson Study. Elinvo (Electronics, Informatics, and Vocational Education), l(1). 